\title{
Effect of Chlorpyrifos on Some Biochemical Constituents in Liver and Kidney of Fresh Water Fish,Channa Gachua (F.Hamilton)
}

\author{
Padmini Kadam ${ }^{1}$, Rajaram Patil ${ }^{2}$ \\ ${ }^{1,2}$ P. G. Department of Zoology, Sadguru Gadge Maharaj College, Karad. 415124 (MS), India
}

\begin{abstract}
Pesticides are most hazardous to human and ambient. These pesticides are used extensively to protect agricultural crops against the damage caused by various kinds of pests. However these chemicals may reach non targeted ecosystems like lakes and rivers through rain and wind, affecting many other organisms. Biochemical variables show specific responses to certain types of environmental stress. The approach of present work was to evaluate toxic effects of an insecticide, chlorpyrifos on biochemical constituents like protein, glycogen and lipid in liver and kidney of freshwater fish, Channa gachua. The biochemical constituents under present study were found to be decreased in both the tissues in comparison with control. So, the result of present study indicates the toxic nature of the insecticide chlorpyrifos.
\end{abstract}

Keywords: chlorpyrifos, biochemical constituents, liver, kidney, Channa gachua.

\section{Introduction}

Fish is an important source of high quality, balanced and easily digestible food material. Fishes have significant role in nutrition, income and employment[1]. Fishes are most important source of animal protein and other element. So it is essential to know the proximate biochemical constituents of the fish and their nutritional composition for public health

Environmental pollution by toxicants has become one of the most important problem in the world. The pesticidal contamination in aquatic ecosystem has attract more attention of researchers[2]. The extensive use of pesticide in agricultural, aquacultural and domestic field has increased in the last decades and becoming threats to living organism. The aquatic organism nothing but the fish are more frequently exposed to these pollutants, it will significantly alters the physiology and metabolism of fish. Fish are the major target organism of toxicant contamination so it is largely used for the assessment of aquatic contamination and serves as bioindicator of environmental pollution. Chlorpyrifos is the second largest selling organophosphorus (OP) insecticide in India. It is broad spectrum pesticide and is more toxic compound. Chlorpyrifos is widely used as agricultural, aquacultural and fishery pest control and due to it's excessive use numerous environmental issues were arisen [3].

Alterations in biochemical components in response to environmental stress are authenticated by many authors e.g. Haloi et. al., in Channa punctatus[4], Sreekala and Zutshi in Labeo rohita[5], Vasantharaja et. al., in Cirrhinus mrigala[6], and Thenmozhi et. al., in Labeo rohita[7]. The previous workers have shown that pesticide can cause alterations in level of biochemical components depending on the toxicant type, species of fish and exposure period. So, keeping these views in mind it is decided to investigate the effect of chlorpyrifos on some biochemical aspects of fish $C$. gachua that may be used as environmental biological indicator of pollution.

\section{Material and Methods}

\subsection{Procurement of test fish}

The fresh water fish, Channa gachua were collected from Krishna river around karad city with the help of fisherman. The fishes having average length $15 \pm 1 \mathrm{~cm}$ and weight about $50 \pm 5 \mathrm{gm}$ were brought to the laboratory and transferred to aerated aquarium for acclimatization. The fishes were fed daily on commercial fish feed.

\subsection{Pesticide}

Organophosphate pesticide chlorpyrifos purchased from local agro chemist shop was used for the present study.

\subsection{Toxicity Studies}

Well acclimatized fishes were transferred into six different aquaria containing different concentrations of chlorpyrifos viz. $0.04,0.045,0.05,0.055,0.06$ and $0.065 \mathrm{ml} / \mathrm{L}$. Fishes were exposed for $96 \mathrm{hrs}$. and recorded the mortality rate of fishes.

\subsection{Plan of Experiment}

For the acute toxicity test the healthy fishes were divided in to three groups, each group containing ten fishes. Group $1^{\text {st }}$ was considered as control and group $2^{\text {nd }}$ and $3^{\text {rd }}$ as experimental groups. Fishes in the experimental group were exposed to sublethal concentration i.e. $0.0125 \mathrm{ml} / \mathrm{L}$ $\left(1 / 4^{\text {th }}\right.$ concentration of $\left.\mathrm{LC}_{50}\right)$ of chlorpyrifos for $24,48,72$ and 96 hrs. At the end of each exposure period the desired organs were excised quickly to evaluate glycogen, protein and lipid contents. The following biochemical methods were used.

\subsection{Biochemical Methods}

2.5.1 Anthrone method - Used to determine total glycogen content in tissues[8]. 


\section{International Journal of Science and Research (IJSR) ISSN (Online): 2319-7064 \\ Index Copernicus Value (2013): 6.14 | Impact Factor (2015): 6.391}

2.5.2 Lowry's Method- Total protein content was determined with Folin Ciocalteau reagent[9].

2.5.3 Sulphophosphovaniline method- Lipid were estimated by Sulphophosphovaniline reagent[10].

\section{Result}

The results obtained in the present investigations are summarized in table 1 and represented graphically in figure 1, 2 and 3. The calculated values of protein, glycogen and lipid content were expressed as $\mathrm{mg} / \mathrm{gm}$ wet wt of tissue. Period dependant decrease in the biochemical constituents was observed throughout the exposure period. The toxicity of chlorpyrifos showed correlation with the concentration of pesticides and period of exposure.

\subsection{Glycogen}

The values were found to be 1.36, 1.18, 1.04 and $0.85 \mathrm{mg} / \mathrm{g}$ wet wt of tissue in liver of fishes exposed for 24, 48, 72 and 96 hrs. respectively which were linearly decreased in comparison with control, $1.84 \mathrm{mg} / \mathrm{g}$ wet wt of tissue. The mean value of kidney glycogen content in the experimental groups were $1.14,0.81,0.64$ and $0.50 \mathrm{mg} / \mathrm{g}$ wet wt. of tissue for 24, 48, 72 and $96 \mathrm{hr}$ exposure of tissue and that of control group was 1.45 .

\subsection{Protein}

In present investigation total protein content of liver in control fish was $51.17 \mathrm{mg} / \mathrm{g}$ wet wt. of tissue where as in treated fish at sublethal concentrations for 24, 48, 72 and 96 hrs were 43.02, 35.82, 31.17 and $24.44 \mathrm{mg} / \mathrm{g}$ wet wt of tissue respectively, these values showing decreasing trend in comparison with control according to exposure period. The protein content in kidney of control fish was 37.88 and that of in experimental fishes were 33.67, 27.58, 21.73 and 17.20 $\mathrm{mg} / \mathrm{g}$ wet wt of tissue for 24 to 96 hrs. which was found decreased considerably.

\subsection{Lipid}

The lipid content in liver was obtained 37.72, 33.27, 28.31 and $26.14 \mathrm{mg} / \mathrm{g}$ wet wt of tissue for 24 ,48, 72, 96 hrs. respectively in experimental group which was decreased considerably when compared with control i.e. $40.64 \mathrm{mg} / \mathrm{g}$ wet wt of tissue. The lipid content in kidney of fish C.gachua was depleted on exposure of pesticide for $96 \mathrm{hrs}$, the lipid content was 46.53, 42.8, 39.7, $35.49 \mathrm{mg} / \mathrm{g}$ wet wt of tissue for 24 to 96 hrs. and that of 49.2 in control fish.

\section{Discussion}

The pesticidal effect on the liver and kidney of experimental fish, C. gachua to various periods revealed a significant decrease in glycogen, protein and lipid content. The changes in biochemical parameters are important to indicate the susceptibility of organ system to pollutants[11]. In an organism toxic substances brings about a kind of stress and an organism responds to that by developing necessary potential[12]. During stress, organism needs sufficient energy which is supplied from reserve food material i.e. protein, glycogen and lipid.

Exposure time dependant decrease in the protein, glycogen and lipid content was observed throughout the experiment. Protein plays a crucial role in virtually all biological processes. Under extreme stress, protein supply energy in metabolic pathways and biochemical reactions[13]. Decrease in protein might be due to the impairment of protein synthesis or increase in the rate of it's degradation to amino acid. This might be fed to TCA cycle aminotransferase to cope with high energy demands to meet the stress condition. Decreased protein content observed in the present investigation was might be due to these reasons. Carbohydrate typically contribute to structural support, protection and serves as nutrient and stored energy which increase or decrease according to organismal need[14]. Carbohydrates are stored as glycogen in fish tissue and organ like liver in order to supply the energy needs when there are hypoxic condition and lack of food[15]. Depletion of glycogen level in the tissue indicates that glycogen acts as major source of energy in fishes exposed to pesticide over come the toxicity stress. Due to these reasons glycogen content might be decreased in present study. Lipid plays an important role in energy metabolism and provide energy to metabolic process[16]. They are also important for cellular membrane. Decrease in lipid content in tissues suggested that the lipid have been channelized to meet the metabolic demand for extra energy need to mitigate the toxic stress. The biochemical constituents in liver and kidney of fish $C$. gachua after sublethal exposure to chlorpyrifos has falls down considerably. In present investigation glycogen, protein and lipid content was reduced significantly in liver and kidney. Reduction in biochemical constituents has been reported by various earlier workers. Decreasing trend in glycogen and protein content was observed in various organs of fish Ctenopharyngodon idellus on exposure to sub lethal concentrations of malathion and fenvalerate by Satyavardhan [17]. Lakshmanan et. al. [18] reported the significant decrease in glycogen, protein and albumin in fish Oreochromis mossambicus during treatment of dichlorvos. Nagraju [19] studied the effect of profenofos and carbosulphan on biochemical characteristics of the fresh water fish Labeo rohita and reported decreased glycogen content in gill, liver, kidney, brain and muscle. Hyalij [11] reported decrease in glycogen, protein and free amino acid in tissues of the Lepidocephalus thermalis due to effect of sugar factory effluent. PadmaPriya and Avsan Maruti [20] observed changes in protein, glycogen, lipid and cholesterol during exposure of imidacloprid in freshwater fish Channa punctatus. Biochemical changes in protein and amino acids in $C$. punctatus in response to sub lethal treatment of the insecticide malathion have been reported by Magar and Shaikh [21]. Thirumurugan et.al., [22] revealed depletion in biochemical parameters like protein and glycogen in Labeo rohita during various periods of exposure to malathion. In grass carp the levels of total protein, cholesterol and glucose indices were reduced significantly by the exposure of atrazin[23]. Binukumari and Saradhamani [24] noticed significant decrease in glycogen, protein and lipid in some tissues of the fish, O. mossambicus after long term exposure of chlorpyrifos. Mohammed [25] observed decrease in biochemical constituents in liver kidney and gill of 


\section{International Journal of Science and Research (IJSR) \\ ISSN (Online): 2319-7064 \\ Index Copernicus Value (2013): 6.14 | Impact Factor (2015): 6.391}

abamectine treated fish $O$. niloticus. Industrial effluents alter the biochemical composition (glycogen, protein and lipid) of the various organs of fish Labeo rohita[26]. Endosulphan mediated biochemical changes in brain, liver and muscle in the fresh water fish Clarius batracus was studied by Tripathi and Verma [27]. Thus, the pesticide toxification disturbs the normal functioning of cell that alters the metabolic processes of the organism.

\section{Conclusion}

In view of above results and discussion, present study showed changes in protein, glycogen and lipid content in fish, that indicates biochemical manifestation due to the toxic action of toxicants. Toxicant induce it's effect at cellular or even at molecular level and ultimately causes biochemical alterations. The changes in biochemical composition of fishes will naturally affect the nutritive value of aquatic fauna and deteriorating the value of fish and it will also great danger to human being due to continuous consumption of such fish.

\section{Acknowledgement}

The author grateful to Principal and Head, Dept of Zoology, S.G.M.College, karad, for providing necessary facilities during present work.

\section{References}

[1] Pawar S.M. and Sonawane S.R. Seasonal variation in muscle glycogen and moisture content of Garramullya and Rasbora daniconius. Int. J. Fauna Biologi. Studies.

[2] 1(5) : 91-94, (2014).

[3] Dutta H.M. and Dalal R. The effect of endosulphan on the ovary of bluegill sun fish: A histhpothological study (Lepomismacrochirus sp.) Int. J. Environ Res. 2: 215224, (2008).

[4] Ahmet Topal, Muhammed Atamanalp, Ertan Oruc, Yeliz Demir, Sukru Beydemir and Alparslan Isik In vivo changes in carbonic anhydrase activity and histopathology of gill and liver tissue after acute exposure to chlorpyrifos in rainbow trout. Arh. HigRadaToksikol 65: 377- 385, (2014).

[5] Haloi Kishor, Monikankana Kalita, Aparajita Borkotoki Acute toxicity of endosulphan on Channa punctatus (Bloch). Int. J. Res. Env. Sci. Techno. 4(3) : 88-92 (2014).

[6] Sreekala G. and Bella Zutshi. Alterations in the biochemical profile and metabolic enzyme in tissues of Labeo rohita. The Bioscan. 7(2) : 359-364, (2012).

[7] Vasantharaja C., K. Pugazhendy., S. Venkatesan., M. Meenambal., S. Prabhakaran and K. Jayachandran. Acute toxicity of cypermethrin and its impact on biochemical alteration in the fresh water fish Cirrhinus mrigala (Hamilton) and Protective effect of Cardiospermum helicacabum (Linn.) 3(1) : 146-152, (2012).

[8] Thenmozhi C., V. Vignesh, R. Thirumurugan, and S. Arun Impact of malathion on mortality and biochemical changes of fresh water fish Labeo rohita. Iran. J. Environ. Health Sci. Eng., 8 (4): 384-394, (2011).

[9] Seifter S., Dayton S., Novic B., Muntwyler E. The estimation of glycogen with the anthrone reagent, Arch, Biochem. Biophy., 25 (1), pp 191-200, (1950).

[10] Lowry O.H; Rosenbrough N.J; Farr A.L .and Randall R.J. Protein measurement with the Folin -phenol reagent ; J. Biol.Chem., 193: 265 -273, (1951).

[11]Barnes, H. and Blackstock, Z.J. Estimation of lipids in marine and tissue. Detailed investigation of the phosphovanilline method for total lipids. Journal of Experimental Marine Biology and Ecology,12, pp. 103118, (1973).

[12] Hyalij M.T. Effect of sugar factory effluent on glycogen, protein and free amino acid content in tissue of the fish Lepidocephalus thermalis., Journal of Environmental Research and Development., 7(3), 12281230, (2013).

[13] Ganeshwade R. M. Biochemical changes induced by dimethote in the liver of of fresh water fish Punctius ticto (Ham).Biological forum an Int. J. 3(2): 65-68, (2011).

[14] Yerragi S.G., Koli V.A., Yerag S. Effect of pesticide malathion on protein metabolism of the marine crab Ucamarionis. J. Ecotoxicol. Environ. Monit, 10(1) : 5962, (2000).

[15] Olangnathan R. and Patterson J. Effect of anthroquinone dyes on the carbohydrates, protein and lipid content in the muscle of Channa punctatus and Cyprinus carpio. Int. J. Pharma. Appli. 4 (1) : 11-18, (2013).

[16] Wendelaar Bonga S.E. The stress response in fish. Phys. Rev., 5: 591-625, (1997).

[17] Gijare S.S. and Tantarpale V.T. Effect of cypermethrin on lipid and cholesterol content of freshwater fish Channa orientalis ( Bloch) Ind. J. Research, 3(8) : 200201, (2014).

[18] Satyavardhan K. Effect of fenvalarate and malathion on biochemical constituents of freshwater fish, Ctenopharyngodon idella. World Applied Sciences Journal, 27(5): 649-655, (2013).

[19] Lakshmanan S., A. Rajendran, C. Sivasubramaniyan Impact of Dichlorvos on tissue glycogen and protein content in freshwater fingerlings, Oreochromis mossambicus (Peters)., International Journal of Research in Environmental Science and Technology,: 3(1): 19-25, (2013).

[20] Nagaraju. B. and Venkata Rathnamma. V. Effect of two pesticides on some biochemical characteristics of the fresh water fish Labeo rohita (Hamilton), Journal of Biology and Today's World, 2(9), 425-441, (2013).

[21] PadmaPriya B. and Avasan Maruthi Y. Imidacloprid toxicity on biochemical constituent in liver tissue of fresh water teleost Channa punctatus. Int J Pharm Bio Sci, 4(4) : 50-54, (2013).

[22] Magar R.S. and Shaikh A. Biochemical changes in protein and amino acids in Channa punctatus in response to sub lethal treatment with the insecticide malathion. Trends in Life Sciences, 1(3) : 19-23, (2012).

[23] Thirumurugan R., Thenmozhi C., VigneshV., Arun S. Impact of malathion on mortality and biochemical changes of fresh water fish Labeo rohita . Iran. J. Environ. Health Sci. Eng., 8(4), pp, 384-394, (2011). 


\section{International Journal of Science and Research (IJSR) \\ ISSN (Online): 2319-7064 \\ Index Copernicus Value (2013): 6.14 | Impact Factor (2015): 6.391}

[24] Soorena A., Jourdehi Y., Ayub, Kazemi, Rezvanollah, Yazdani, Ali M. Effect of atrazine ( herbicide) on blood biochemical indices of grass carp (Ctenopharhyngoden idella) Journal of the parsian gulf, 2( 5) : 51-56, ( 2011).

[25] Saradhamani N. and Binukumari S. Impact of (Chlorpyrifos) on the biochemical components of the fish, Oreochromis mossambicus (Peters, 1852), Current Biotica, 5(1), 79-84, (2011).

[26] Mohammed A. Al Khatani Effect of an insecticide abamectine on some biochemical characteristics of tilapia fish (Oreochromis niloticus) American J. Agri. Biol. Sci. 6(1) : 62-68, (2011).

[27] Muley D.V., Karanjkar D.M., Maske S.V. Impact of industrial effluent on the biochemical composition of fresh water fish Labeo rohita, Journal of Environmental Biology, 28(2), 245-249, (2007).

[28] Tripathi G. and Verma P. Endosulphan mediated biochemical changes in the fresh water fish Clarius batracus. Biomedical and Environmental Sciences ,17 : 47-56, (2004).

Table 1: Table showing relative changes in Glycogen, Protein and Lipid content in liver and kidney of C. gachua exposed to sub lethal concentration of chlorpyrifos for 24, 48, 72 and 96 hrs.

\begin{tabular}{|c|c|c|c|c|c|c|}
\hline Tissue & Biochemical constituent & control & 24hrs & 48hrs & 72hrs & 96hrs \\
\hline \multirow{4}{*}{ Liver } & Glycogen & $1.84 \pm 0.008$ & $1.36 \pm 0.01$ & $1.18 \pm 0.01$ & $1.04 \pm 0.005$ & $0.85 \pm 0.001$ \\
\cline { 2 - 7 } & Protein & $51.17 \pm 0.23$ & $43.02 \pm 0.19$ & $35.82 \pm 0.34$ & $31.17 \pm 0.28$ & $24.44 \pm 0.48$ \\
\cline { 2 - 7 } & Lipid & $40.64 \pm 0.28$ & $37.72 \pm 0.08$ & $33.27 \pm 0.10$ & $28.31 \pm 0.15$ & $26.14 \pm 0.11$ \\
\hline \multirow{3}{*}{ Kidney } & Glycogen & $1.45 \pm 0.02$ & $1.14 \pm 0.01$ & $0.81 \pm 0.01$ & $0.64 \pm 0.006$ & $0.50 \pm 0.002$ \\
\cline { 2 - 7 } & Protein & $37.88 \pm 0.58$ & $33.67 \pm 0.19$ & $27.58 \pm 0.19$ & $21.73 \pm 0.31$ & $17.20 \pm 0.25$ \\
\cline { 2 - 7 } & Lipid & $49.2 \pm 0.4$ & $46.53 \pm 0.07$ & $42.8 \pm 0.10$ & $39.7 \pm 0.11$ & $35.49 \pm 0.10$ \\
\hline
\end{tabular}

Values expressed $\mathrm{mg} / \mathrm{g}$ wet wt of tissues.

Values are expressed as mean \pm S.E., Sample size $(n)=5$.

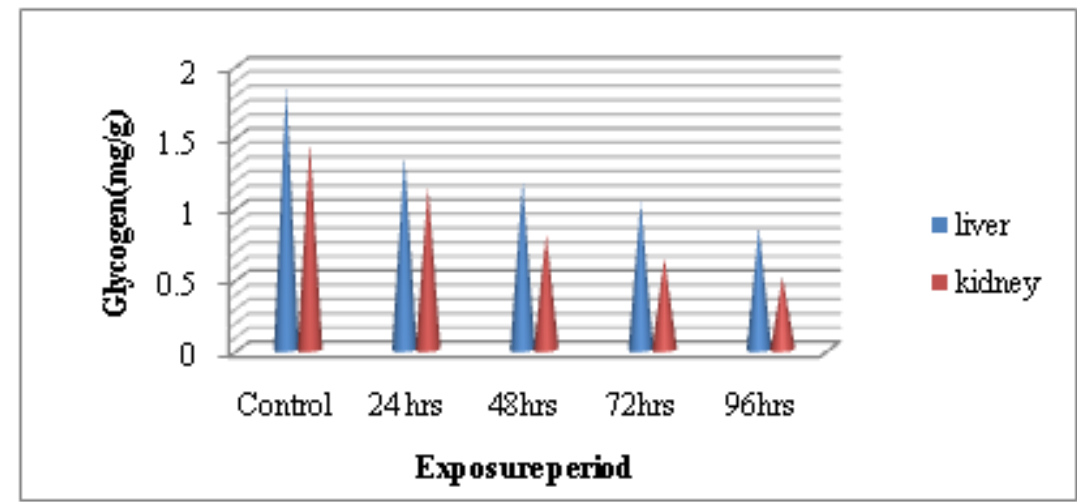

Figure 1: Relative changes in glycogen content (mg/g wet wt of tissue) in liver and kidney of fish C. gachua, exposed to sublethal concentration of chlorpyrifos for 24, 48, 72 and 96 hrs.

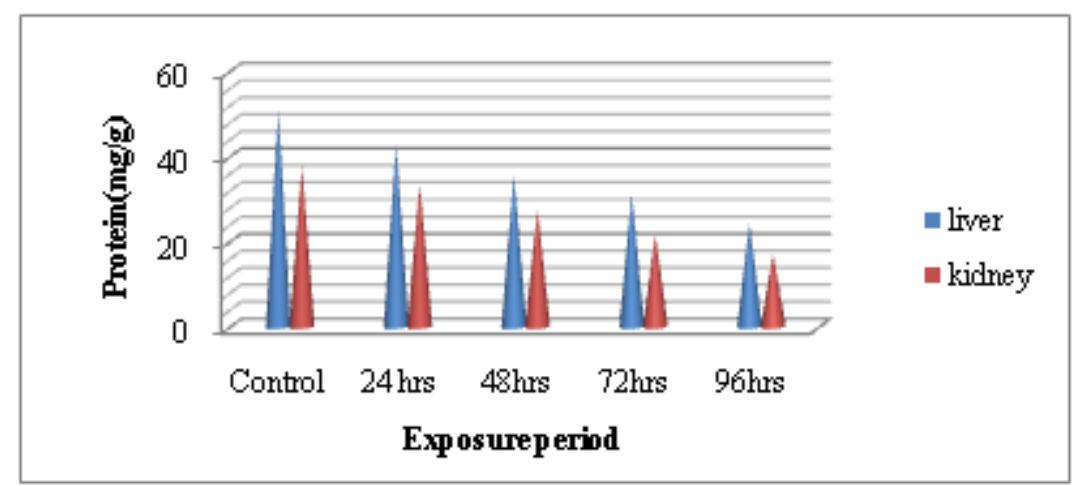

Figure 2: Relative changes in protein content (mg/g wet wt of tissue) in liver and kidney of fish C. gachua, exposed to sublethal concentration of chlorpyrifos for 24, 48, 72 and 96 hrs. 


\section{International Journal of Science and Research (IJSR) \\ ISSN (Online): 2319-7064}

Index Copernicus Value (2013): 6.14 | Impact Factor (2015): 6.391

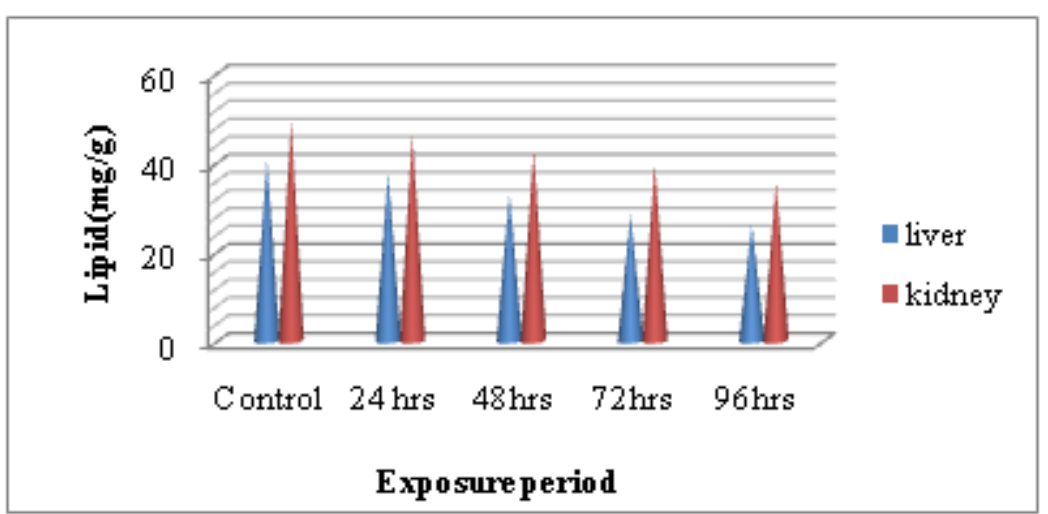

Figure 3: Relative changes in lipid content (mg/g wet wt of tissue) in liver and kidney of fish C. gachua, exposed to sublethal concentration of chlorpyrifos for 24, 48, 72 and 96 hrs.

\section{Author Profile}

Padmini kadam I had received the B.Sc. and M.Sc. degrees in Zoology from Y.C. College Karad and S.G.M. College karad of Shjivaji university, kolhapur respectively. Now I pursuing Ph.D. under the guidance of Dr.R.N.Patil sir from S.G.M. College karad, Shjivaji university Kolhapur. 